UDC 613.26; 614.31

DOI: $10.21668 /$ health.risk/2019.3.05.eng

\title{
ANALYZING HEALTH RISKS FOR EMPLOYABLE POPULATION CAUSED BY FOOD PRODUCTS CONTAMINATION (EXPERIENCE GAINED IN SAMARA REGION)
}

\author{
D.O. Gorbachev, O.V. Sazonova, L.M. Borodina, M.Y. Gavryushin
}

Samara State Medical University, 89 Chapayevskaya Str., Samara, 443099, Russian Federation

Nowadays it is essential to provide safe nutrition for population via activities aimed at reducing risks related to adverse effects produced by contaminants on people's health; such activities include those accomplished within the state sanitary-epidemiologic surveillance. As per data provided by Samara Regional Center for Hygiene and Epidemiology, 71,204 food products samples were analyzed; analysis focused on contents of heavy metals (cadmium, mercury, lead, and arsenic), pesticides (hexachlorocyclohexane or HCCH, Dichlorodiphenyltrichloroethane or DDT,) nitrates, nitrites, aflatoxin B1, and benzpyrene. Next, exposure was assessed and risks of carcinogenic and non-carcinogenic effects were calculated. Analysis of an aggregated hazard index created as per median values of contaminants contents revealed that arsenic made a substantial contribution into risks which was equal to $48 \%$. The second rank place belonged to cadmium that accounted for $14 \%$; the third one was occupied with nitrates, $12 \%$. The following food products groups contributed into the aggregated hazard index: melons and vegetables (23\%), bread and grocery (22\%), milk and milk products (12\%), meat and meat products (11\%), fruit and berries (9\%). It was shown that simultaneous introduction of the examined contaminants taking into account the highest non-carcinogenic risks exerted the most adverse impacts on the hormonal system due to combined exposure to cadmium, mercury, lead, arsenic, and DDT. We assessed carcinogenic risks caused by combined introduction of the contaminants taking into account their median concentrations and revealed that the risks were within the third range. We designed evolution models for carcinogenic risks basing on calculated consumption of various food products both as per median concentrations and 90\%-percentile; it allowed us to assess these risks as being "negligible". It was shown that the state sanitary-epidemiologic surveillance in Samara region accomplished all the necessary activities as regards monitoring over quality and safety of food products, both domestic and imported.

Key words: contamination, heavy metals, pesticides, food products, non-carcinogenic risks, carcinogenic risks, evolution models, food security.

Nutrition plays a key role in protecting and preserving people's health $[1,2]$. Components in nutrition provide a body with all the necessary macro- and microelements; food is a source of energy; nutrients that are contained in a ration exert their influence on body growth and development and protect it from adverse effects produced by environmental factors [3-7]. But still, alien components that occur in food raw materials and food products can exert negative impacts on human health via reducing adaptation potential of a body; in its turn, it can result in carcinogenic and non-carcinogenic effects [8-13]. Food products contamination primarily occurs due to anthropogenic reasons as it is closely connected with economic activities performed by people [14-19]. At present there are certain activities that are being accomplished within implementation of such documents as

(C) Gorbachev D.O., Sazonova O.V., Borodina L.M., Gavryushin M.Y., 2019

Dmitry O. Gorbachev - Candidate of Medical Sciences, Associate professor at the Nutrition Hygiene Department with a course in hygiene for children and teenagers (e-mail: Dmitriy-426@rambler.ru; tel.: +7(846) 332-70-89; ORCID: https:// orcid.org/0000-0002-8044-9806).

Olga V. Sazonova - Doctor of Medical Sciences, head of the Nutrition Hygiene Department with a course in hygiene for children and teenagers (e-mail: ov_2004@mail.ru; tel.: +7(846) 332-70-89; ORCID: https://orcid.org/0000-0002-4130-492X).

Lyubov M. Borodina - Candidate of Medical Sciences, Associate professor at the Nutrition Hygiene Department with a course in hygiene for children and teenagers, Leading Researcher (e-mail: smlm@mail.ru; tel.: +7(846) 332-70-89; ORCID: https://orcid.org/0000-0002-5165-8254).

Mikhail Yu. Gavryushin - Candidate of Medical Sciences, Senior Lecturer at the Nutrition Hygiene Department with a course in hygiene for children and teenagers, Leading Researcher (e-mail: muiltex555@yandex.ru; tel.: +7(846) 332-70-89; ORCID: https://orcid.org/0000-0002-0897-7700). 
"The Doctrine of Food Security in the Russian Federation"1, "The Basics of the state policy as regards providing healthy nutrition to population up to 2020 "2, "The Strategy for improving quality of food products in the Russian Federation up to $2030{ }^{3}$; ; these activities are aimed at reducing risks of adverse effects produced by contaminants in food on human health and they are accomplished, among other things, via the state system for sanitary-epidemiologic surveillance [20]. Monitoring over quality and safety of food products, both produced domestically and imported from abroad, is an efficient tool that allows achieving the above-mentioned goals. This monitoring is performed within the social-hygienic monitoring system due to the Federal Information Fund (FIF) functioning. All the data that are accumulated due to monitoring give grounds for taking administrative measures that can include products being withdrawn from distribution, ban on food products imports, or imposing limitations on their application. Besides, monitoring activities also involve assessing health risks caused by contamination of food products and food raw materials. Monitoring results are applied to make managerial decisions and to provide customers with information on food products $[21,22]$. Nowadays experts in Russia apply methodic approaches based on unified risk assessment criteria and consisting of several stages; these stages are hazard identification, assessment of "exposure - response" relationship, assessment of exposure, and risk characteristics. Mathematical modeling of risks evolution over time is a promising trend in risk assessment. This approach allows the most precise estimation of probable impacts exerted by alimentary contaminants on various organs and systems in living objects [23].

So, we should consider influence exerted by nutrition on a human body not only in terms of its ability to satisfy its physiological needs in nutrients and energy but also in terms of potential risks caused by anthropogenic contaminants contained in food raw materials and products. We should note that adverse effects produced by the said contamination are aggravated when people work under hazardous conditions and/or when they don't adhere to the principles of rational and healthy nutrition. All the above-mentioned issues determined our research goal and methodology; our research object was Samara region, an average statistical one in the RF.

Our research goal was to assess health risks for employable population in Samara region caused by food products contamination.

Data and methods. We assessed admixtures in food products as per data collected over 11 years and provided by the laboratory of the Samara Regional Center for Hygiene and Epidemiology. We analyzed 71,204 samples during our research and made a data array that was applied to create a database entitled "the Database on food products contamination" that allowed collecting, storage, and dynamic processing of data on food products contamination. We applied median and 90-th percentile of contaminant contents in food products in order to calculate exposure. We examined food products that were both produced locally and brought to the region from other territories, including imports. We determined contents of heavy metals (cadmium,

\footnotetext{
${ }^{1}$ On Approval of the Doctrine of Food Security in the Russian Federation: The RF President Order dated January 30, 2010 No. 120. Rossiyskaya gazeta, 2010, the Federal issue No. 21 (5100). Available at: https://rg.ru/2010/02/03/proddok.html (date of visit May 10, 2019).

${ }^{2}$ The Basics of the state policy as regard providing healthy nutrition to population up to 2020: The RF Government Order dated October 25, 2010 No. 1873-r. KonsultantPlus. Available at: http://www.consultant.ru/document/cons_doc_LAW_106196/abb337778165250dae206cadc6dc91e21308f022/(date of visit May 10, 2019).

${ }^{3}$ On Approval of the Strategy for improving quality of food products in the Russian Federation up to 2030: The RF Government Order dated June 29, 2016 No.1364-r. The official web-site of the RF Government. Available at: http://government.ru/docs/23604/ (date of visit May 10, 2019).

${ }^{4}$ Baturin A.K., Martinchik A.N., Gorbachyov D.O., Sazonova O.V., Mikhailov N.A. The Certificate of the state registration of a PC program 2018616624 RF. "Nutri-prof" software package for assessing actual nutrition. The Federal Research Center for Nutrition and Biotechnology, Samara State Medical University of the RF Public Healthcare Ministry. No. 2018613172. Bulletin No. 6, 1 p.
} 
mercury, lead, and arsenic), pesticides (hexachlorocyclohexane $(\mathrm{HCCH}), \mathrm{DDT})$, nitrates, nitrites, aflatoxin $\mathrm{B} 1$, and benzpyrene in all examined food products. Exposure was assessed and risks of carcinogenic and noncarcinogenic effects were calculated automatically according to "the Guidelines on assessment of population health risks under exposure to chemicals that pollute the environment", Total hazard index (HI) was calculated for a single-time introduction and long-term exposure to several contaminants as per median values of exposure and its 90-th percentile.

We assessed carcinogenic risks basing on calculated values of exposure to contaminants as per median and the 90-th percentile taking into account factors of carcinogenic potential (slope factors). In addition we calculated population carcinogenic risk (per 10,000 people).

Workers employed at industrial enterprises, educational establishments, medical organizations, agricultural companies, and office personnel took part in our research; they all permanently lived in Samara region. Our sampling included 1,736 people. Unlike a methodology for exposure calculation based on the data on average annual food products consumption per capita (applied by the Federal Statistics Service), we applied data on individual average annual food products consumption obtained via assessing actual nutrition consumed by employable population. The assessment was based on a methodology that involved 24-hour reproduction of a ration with "Nutri-prof" software package.

To assess health risks caused by food products contamination, we additionally used calculation forms of evolution models. They were based on recurrence relations for different responses to exposure that became apparent via health disorders [24].

Results and discussion. We analyzed distribution of the examined samples and revealed that fruit and vegetables accounted for the greatest share of samples $(28 \%)$; all the other food product groups on average accounted for $12-14 \%$. The greatest number of samples was local food products, and only $18.2 \%$ were products brought to the region from other territories.

We analyzed contaminants contents in food products and revealed the greatest cadmium concentrations as per median values in milk and milk products, sugar and confectionary (mostly in cacao beans), fish and fish products, bread and groceries; the smallest cadmium concentrations were detected in eggs and potatoes (the median value spread was $0.04-0.0125 \mathrm{mg} / \mathrm{kg}$ ). The greatest quantities of mercury were detected in fish and fish products; as for the other food products, they had mercury in almost identical concentrations, the median value spread being $0.0161-0.0013 \mathrm{mg} / \mathrm{kg}$.

Analysis of lead contents in food products revealed its maximum median concentrations in fish and fish products, potatoes, bread and groceries, the median value spread being $0.076-0.02 \mathrm{mg} / \mathrm{kg}$.

We ranked food products as per median concentrations of arsenic and revealed that fish and fish products, potatoes, bread and groceries contained this metal in the greatest quantities, the value spread being $0.0691-0.0122 \mathrm{mg} / \mathrm{kg}$.

The maximum $\mathrm{HCCH}$ median concentrations were detected in eggs, vegetable oil, and other fats. The lowest concentrations were detected in vegetable products such as vegetables, fruits, and potatoes, the value spread being $0.0163-0.0032 \mathrm{mg} / \mathrm{kg}$. DDT was detected in the greatest concentrations in meat and meat products, vegetable oil, and other fats, the value spread being $0.0143-0.0044 \mathrm{mg} / \mathrm{kg}$.

The greatest median nitrates concentrations were detected in potatoes, vegetables, and melons, the value spread being 56.48-87.3 $\mathrm{mg} / \mathrm{kg}$. Median nitrates concentration in berries amounted to $26.456 \mathrm{mg} / \mathrm{kg}$. The maximum nitrates concentration was detected in meat

\footnotetext{
${ }^{5}$ G 2.1.10.1920-04. The Guidelines on assessment of population health risks under exposure to chemicals that pollute the environment. Moscow, The Federal Center for State Sanitary-Epidemiologic Surveillance of the RF Public Healthcare Ministry Publ., 2004, 143 p.
} 
and meat products (sausages, boiled sausage, and smoked sausage).

We ranked food products as per median concentrations of aflatoxin $\mathrm{B} 1$ and revealed its greatest concentrations in vegetable oil and other fats, bread and groceries, sugar and confectionary, the value spread being $0.0002-0.00019 \mathrm{mg} / \mathrm{kg}$. The greatest benzpyrene concentrations as per median values were detected in fish and fish products, meat and meat products, the value spread being $0.0002-0.0004 \mathrm{mg} / \mathrm{kg}$.

The data we obtained on admixtures contents in food products together with data on individual average annual consumption obtained via assessing actual nutrition consumed by employable population, allowed us to calculate exposure and hazard quotients for noncarcinogenic effects produced by exposure to anthropogenic contaminants (Table 1).

\section{Table 1}

Exposure (EXP, $\mathrm{mg} / \mathrm{kg} /$ day) and hazard quotients (HQ) for non-carcinogenic effects produced by exposure to anthropogenic contaminants as per median and 90-the percentile

\begin{tabular}{|l|c|c|c|c|}
\hline $\begin{array}{c}\text { Contami- } \\
\text { nants }\end{array}$ & $\mathrm{EXP}_{\text {ме }}$ & $\mathrm{EXP}_{90}$ & $\mathrm{HQ}_{\text {ме }}$ & $\mathrm{HQ}_{90}$ \\
\hline Cadmium & 0.00013 & 0.00028 & 0.27 & 0.56 \\
\hline Mercury & $4.28097 \mathrm{E}-05$ & 0.00014 & 0.14 & 0.48 \\
\hline Lead & 0.00061 & 0.0017 & 0.17 & 0.50 \\
\hline Arsenic & 0.00027 & 0.00057 & 0.89 & 1.9 \\
\hline HCCH & $7.55513 \mathrm{E}-05$ & 0.000601 & 0.0075 & 0.0604 \\
\hline DDT & $8.79349 \mathrm{E}-05$ & 0.00022 & 0.175 & 0.45 \\
\hline Nitrates & 0.3462 & 1.0085 & 0.22 & 0.63 \\
\hline Nitrites & $2.40469 \mathrm{E}-05$ & 0.028 & 0.00024 & 0.28 \\
\hline $\begin{array}{l}\text { Aflatoxin } \\
\text { B1 }\end{array}$ & $9.23169 \mathrm{E}-07$ & $1.08517 \mathrm{E}-05$ & 0.0185 & 0.217 \\
\hline $\begin{array}{l}\text { Ben- } \\
\text { zpyrene }\end{array}$ & $2.03296 \mathrm{E}-07$ & $1.50772 \mathrm{E}-06$ & 0.00041 & 0.003 \\
\hline
\end{tabular}

Total hazard index as per median amounted to 1.9; as per 90-th percentile, to 5 . We detected substantial contributions made by the following contaminants into the total hazard index calculated as per median contaminants concentrations: arsenic, $48 \%$; the second rank place belonged to cadmium, $14 \%$; the third place was taken by nitrates, $12 \%$. Contri- butions made by contaminants into total hazard index as per 90-th percentile were distributed as follows: the first rank place belonged to arsenic (37\%); the second one, nitrates $(13 \%)$; the third one, cadmium $(11 \%)$. Basic product groups that made the most substantial contribution into the total hazard index were vegetables and melons (23\%), bread and groceries $(22 \%)$, milk and milk products $(12 \%)$, meat and meat products $(11 \%)$, fruit and berries $(9 \%)$.

We considered a scenario when all the examined contaminants were introduced simultaneously taking into account maximum non-carcinogenic risks and revealed the highest risks of probable adverse effects for the hormonal system due to combined exposure to cadmium, mercury, lead, arsenic, and DDT (Table 2).

Table 2

Total hazard index (HI) under combined effects produced by contaminants on critical organs and systems (90-th percentile)

\begin{tabular}{|l|c|}
\hline Critical organs and systems/contaminants & HI \\
\hline $\begin{array}{l}\text { Hormonal system (cadmium, mercury, lead, } \\
\text { arsenic, and DDT) }\end{array}$ & 3.6 \\
\hline Nervous system (mercury, lead, and arsenic) & 2.7 \\
\hline Immune system (mercury and arsenic) & 2.2 \\
\hline Cardiovascular system (arsenic and nitrates) & 2.4 \\
\hline Reproductive system (mercury and lead) & 0.9 \\
\hline Skin (arsenic) & 1.8 \\
\hline Kidneys (cadmium and mercury) & 0.9 \\
\hline Gastrointestinal tract (arsenic) & 1.8 \\
\hline Blood (lead, nitrates, and nitrites) & 0.9 \\
\hline Liver (DDT) & 0.4 \\
\hline
\end{tabular}

We detected that maximum individual and population carcinogenic risks were caused by exposure to arsenic taking into account median values of exposure to contaminants; if we took exposure values as per 90-th percentile, the maximum risks were caused by exposure to $\mathrm{HCCH}$ and arsenic (Table 3).

We assessed carcinogenic risks caused by combined exposure to contaminants taking into account their median concentrations and revealed that the risk level corresponded to the third range (individual lifelong risk was within a range from $1 \mathrm{E}-04$ to $1 \mathrm{E}-03$ ) which was ac- 
ceptable for occupational groups and unacceptable for population in general. We also assessed carcinogenic risks under combined lifelong exposure to contaminants as per 90-th percentile and revealed that the risk was within the fourth range and was characterized as unacceptable (individual lifelong risk was equal to or higher than 0.001 ); it called for immediate organizational activities aimed at reducing the said risk.

Table 3

Individual and population carcinogenic risks caused by exposure to contaminants

(as per median and 90-th percentile)

\begin{tabular}{|l|c|c|c|c|}
\hline Contaminants & $\mathrm{CR}_{\mathrm{Me}}$ & $\mathrm{PCR}_{\mathrm{Me}}$ & $\mathrm{CR}_{90}$ & $\mathrm{PCR}_{90}$ \\
\hline Cadmium & $5.15 \mathrm{E}-05$ & 0.5 & 0.000107 & 1.07 \\
\hline Lead & $2.8 \mathrm{E}-05$ & 0.28 & $7.9 \mathrm{E}-05$ & 0.79 \\
\hline Arsenic & 0.00040 & 4 & 0.00086 & 8.6 \\
\hline DDT & $2.9 \mathrm{E}-05$ & 0.29 & $7.6 \mathrm{E}-05$ & 0.76 \\
\hline Benzpyrene & $1.4 \mathrm{E}-06$ & 0.01 & $1.1 \mathrm{E}-05$ & 0.11 \\
\hline HCCH & 0.000135 & 1.35 & 0.00108 & 10.8 \\
\hline$\sum$ & $6.45 \mathrm{E}-04$ & 6.43 & 0.00221 & 22.13 \\
\hline
\end{tabular}

We built evolution models for combined introduction of contaminants taking into account individual average annual consumption; it allowed us to determine groups of products that caused the highest risks as well as organs and systems that were the most susceptible to adverse effects produced by contaminants. Our calculations revealed that the earliest transition of a risk from being "negligible" to being "moderate" happened at an age equal to 58.2 years when bread and groceries were con- sumed and then the risk caused by this product group turned into "high" at an age of 74.8; when milk and milk products were consumed, the risk became "high" at 74.9; the risk caused by bread and groceries became "extremely high" at 76 (Figure 1).

When we applied concentrations as per 90th percentile to assess combined introduction of contaminants ("pessimistic scenario of consumption"), the youngest age at which risk became "moderate" was also detected for bread and groceries and was equal to 41.2 years; the risk became "high" at 66.1 for this product group and "extremely high" at 70.4.

Our assessment of effects produced by contaminants on a body revealed that the most significant adverse effects were produced by cadmium, arsenic, and $\mathrm{HCCH}$; effects were primarily produced on the endocrine system (Figure 2).

We built evolution models for noncarcinogenic risks caused by exposure to contaminants for other organs and systems (the cardiovascular system, urogenital system, hematopoietic system, and immune system) and assessed them to be "negligible".

We also created evolution models for carcinogenic risks taking into account calculated consumption of bread and groceries; the risks were caused by adverse effects produced by cadmium, arsenic, $\mathrm{HCCH}$, and DDT and were calculated as per median concentrations and 90-th percentile. Both calculations allowed us to assess risks caused by the said contaminants to be "negligible".

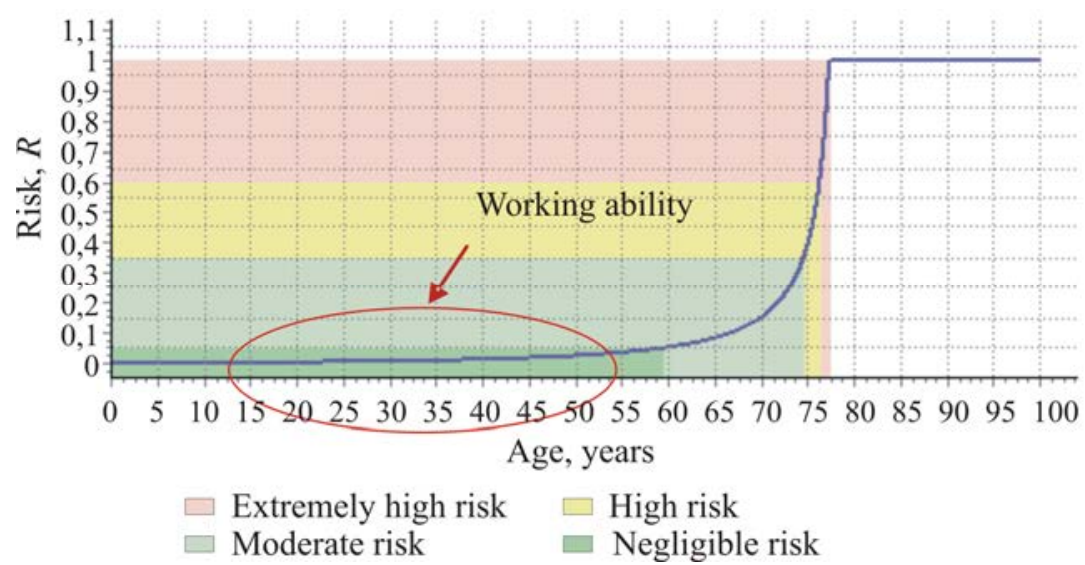

Figure 1. Reduced non-carcinogenic risk index for calculated consumption of bread and groceries 


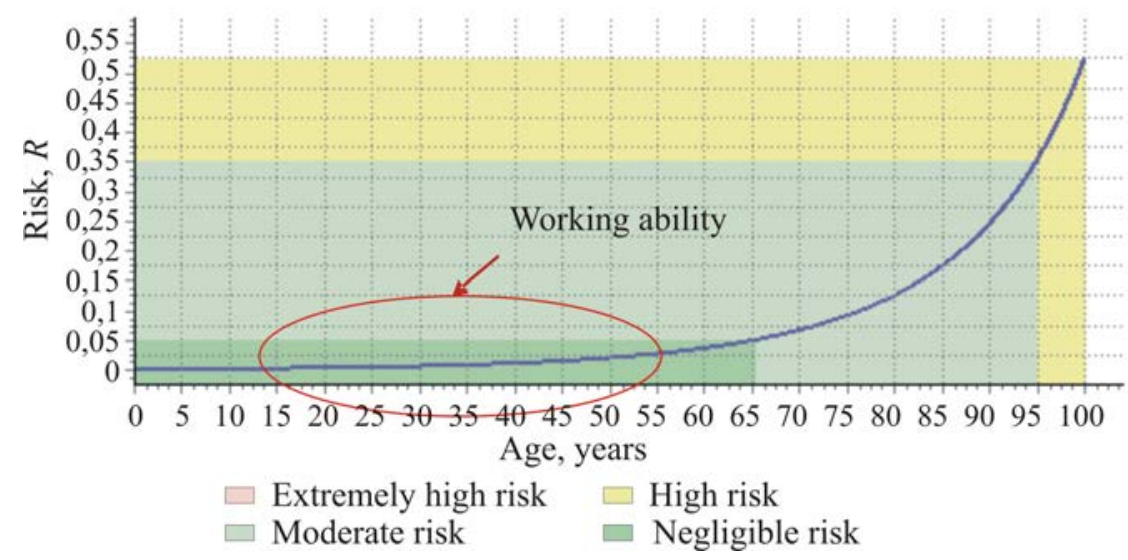

Figure 2. Reduced non-carcinogenic risk index (the endocrine system) for calculated consumption of bread and groceries

Conclusions. In order to assess risks in our research, we took data on individual average annual consumption of food products obtained via assessing actual nutrition consumed by employable population basing on a technique that reproduced a 24-hour nutrition scheme. The procedure that we propose allows maximum possible precision in determining impacts exerted by alimentary contaminants as it is not based on statistical data on average annual food products consumption per capita.

We revealed in our research that the maximum hazard quotient for non-carcinogenic effects was caused by arsenic being introduced with food. Total hazard index under combined exposure to the examined contaminants, both in their median and 90-th percentile concentrations, was predominantly caused by introduction of arsenic, cadmium, and nitrates contained in vegetables and melons, bread and groceries, milk and milk products, meat and meat products, fruits and berries. We detected that the endocrine system was the most susceptible to adverse effects produced by combined exposure to cadmium, mercury, lead, arsenic, and DDT, and it was also con- firmed by evolution models. We assessed carcinogenic risks caused by combined exposure to contaminants taking into account their median concentrations; the assessment revealed that risk level was within the third range; when 90-th percentile concentrations were considered, the risk was within the fourth range. We built evolution models for carcinogenic risks basing on calculated food products consumption and resulting contaminants contents both in their median concentrations and 90-th percentile and it allowed us to assess risks caused by the said effects as being "negligible".

Therefore, application of various methodical approaches to assessing risks caused by food products contamination revealed that the state system of sanitary-epidemiologic surveillance in Samara region provided all the necessary monitoring over safety and quality of food products, both domestically produced and imported ones, and made for preservation of population health.

Funding. The research was not granted any sponsor support.

Conflict of interests. The authors declare there is no any conflict of interests.

\section{References}

1. Frolova O.A., Tafeeva E.A., Frolov D.N., Bocharov E.P. Alimentary-dependent diseases of the population and the hygienic characteristic of the factors of the risk of their development in the territory of the republic of Tatarstan. Gigiena i sanitariya, 2018, vol. 97, no. 5, pp. 470-473 (in Russian).

2. Pastushkova E.V., Mysakov D.S., Chugunova O.V. Some aspects of nutrition and health. Zdorov'e i obrazovanie v XXI veke, 2016, no. 4, pp. 67-72 (in Russian). 
3. Lebedeva S.N., Zhamsaranova S.D., Chukaev S.A., Dymsheeva L.D. Assesment of the nutrition and antioxidant activity of biological liquids in students. Voprosy pitaniya, 2018, no. 1, pp. 35-43 (in Russian).

4. Mazhaeva T.V., Dubenko S.E., Pogozheva A.V., Khotimchenko S.A. Characteristics of the diet and nutritional status of workers at various industrial enterprises of the Sverdlovsk Region. Voprosy pitaniya, 2018, no. 1, pp. 72-78 (in Russian).

5. Evstratova V.S., Radzhabkadiev R.M., Khanfer'yan R.A. The structure of macronutrient consumption by the population of various regions of Russian Federation. Voprosy pitaniya, 2018, no. 2, pp. 34-38 (in Russian).

6. Boyarskaya L.A., Vil'ms E.A., Turchaninov D.V. Hygienic substantiation of application of functional dairy products in the prevention of macro- and micronutrient deficiency. Gigiena i sanitariya, 2016, vol. 95, no. 11, pp. 1095-1099 (in Russian).

7. Zhminchenko V.M., Gapparov M.M.G. Modern trends of research in nutritiology and nutrition hygiene. Voprosy pitaniya, 2015, no. 1, pp. 4-14 (in Russian).

8. Khotimchenko S.A., Bessonov V.V., Bagryantseva O.V., Gmoshinskii I.V. Safety of food products: new problems and ways of solution. Meditsina truda i ekologiya cheloveka, 2015, no.4, pp. 7-14 (in Russian).

9. Klepikov O.V., Khatuaev R.O., Istomin A.V., Rumyantseva L.A. Regional features of food standards and health risks associated with chemical contamination of food. Gigiena i sanitariya, 2016, vol. 95, no. 11, pp. 1086-1091 (in Russian).

10. Al-Saleh I., Abduljabbar M. Heavy metals (lead, cadmium, methylmercury, arsenic) in commonly imported rice grains (Oryza sativa) sold in Saudi Arabia and their potential health risk. Int. J. Hyg. Environ Health, 2017, vol. 220, no. 7, pp. 1168-1178. DOI: 10.1016/j.ijheh.2017.07.007

11. Fang Y., Sun X., Yang W., Ma N., Xin Z., Fu J., Liu X., Liu M. [et al.]. Concentrations and health risks of lead, cadmium, arsenic, and mercury in rice and edible mushrooms in China. Food Chem., 2014, vol. 15, no. 147, pp. 147-151. DOI: 10.1016/j.foodchem.2013.09.116

12. Jiang Y., Zeng X., Fan X., Chao S., Zhu M., Cao H. Levels of arsenic pollution in daily foodstuffs and soils and its associated human health risk in a town in Jiangsu Province, China. Ecotoxicol. Environ. Saf, 2015, no. 122, pp. 198-204. DOI: 10.1016/j.ecoenv.2015.07.018

13. Sadeghi F., Nasseri S., Yunesian M., Nabizadeh R., Mosaferi M., Mesdaghinia A. Carcinogenic and non-carcinogenic risk assessments of arsenic contamination in drinking water of Ardabil city in the Northwest of Iran. J. Environ. Sci. Health. A. Tox. Hazard Subst. Environ., 2018, vol. 53, no. 5, pp. 421-429. DOI: 10.1080/10934529.2017.1410421

14. Lamteva T.V., Velikaya L.V., Gaidukova E.P., Platunin A.V. About contamination by nitrates of crop production. Prikladnye informatsionnye aspekty meditsiny, 2018, no. 4, pp. 111-117 (in Russian).

15. Tutelyan V.A., Nikityuk D.B., Khotimchenko S.A. Normative base for food quality and safety assessment. Rossiiskii zhurnal vosstanovitel'noi meditsiny, 2017, no. 2, pp. 74-120 (in Russian).

16. Liu J., Zhuo Z., Sun S., Ning X., Zhao S., Xie W., Wang Y., Zheng L. [et al.]. Concentrations of heavy metals in six municipal sludges from Guangzhou and their potential ecological risk assessment for agricultural land use. Pol. J. Environ. Stud, 2015, vol. 24, no. 1, pp. 165-174. DOI: $10.15244 /$ pjoes $/ 28348$

17. Perez-Vazquez F.J., Flores-Ramirez R., Ochoa-Martínez A.C., Carrizales-Yanez L., Ilizaliturri-Hernandez C.A., Moctezuma-Gonzalez J., Pruneda-Alvarez L.G., Ruiz-Vera T. [et al.] Human health risks associated with heavy metals in soil in different areas of San Luis Potosi, Мехісою Hum. Ecol. Risk Assess, 2016, vol. 22, no. 2, pp. 323-336. DOI: 10.1080/10807039.2015.1064760

18. Kendir E., Kentel E., Sanin F.D. Evaluation of heavy metals and associated health risks in a metropolitan wastewater treatment plant's sludge for its land application. Hum. Ecol. Risk Assess. Int, 2015, vol. 21, no. 6, pp. 1631-1643. DOI: 10.1080/10807039.2014.966590

19. Chen T.B., Huang Q.F., Gao D. [et al.]. Heavy metal concentrations and their decreasing trends in sewage sludges of China. Acta Sci. Circumstantiate, 2003, no. 23, pp. 561-569.

20. Popova A.Yu. Risk analysis as a strategic sphere in providing food products safety. Health Risk Analysis, 2018, no. 4, pp. 4-12. DOI: 10.21668/health.risk/2018.4.01.eng 
21. Zaitseva N.V., Tutelyan V.A., Shur P.Z., Khotimchenko S.A., Sheveleva S.A. Experience of justification of hygienic standards of food safety with the use of criteria for the risk for population health. Gigiena i sanitariya, 2014, no. 5, pp. 70-74 (in Russian).

22. Zaitseva N.V., Popova A.Yu., May I.V., Shur P.Z. Methods and technologies of health risk analysis in the system of state management under assurance of the sanitation and epidemiological welfare of population. Gigiena i sanitariya, 2015, no. 2, pp. 93-98 (in Russian).

23. Zaitseva N.V. Analysis of population health risks in the Russian Federation caused by food products contamination. Health Risk Analysis, 2018, no. 4, pp. 13-23. DOI: 10.21668/health.risk/2018.4.02.eng

24. Zaitseva N.V., Shur P.Z., Kiryanov D.A., Kamaltdinov M.R., Tsinker M.Yu. Methodical approaches for health population risk estimation based evolution models. Zdorov'e naseleniya i sreda obitaniya, 2013, no. 1, pp. 4-6 (in Russian).

Gorbachev D.O., Sazonova O.V., Borodina L.M., Gavryushin M.Y. Analyzing health risks for employable population caused by food products contamination (experience gained in Samara region). Health Risk Analysis, 2019, no. 3, pp. 42-49. DOI: 10.21668/health.risk/2019.3.05.eng

Received: 25.06 .2019

Accepted: 26.07.2019

Published: 30.09.2019 